\title{
Quality control of vaccines-A journey from classical approach to 3Rs.
}

\author{
Suresh Kumar ${ }^{1 *}$, Mahendra Pal Singh¹, Vijay K. Bharti², Ramendra Pati Pandey ${ }^{3}$ \\ ${ }^{1}$ National Institute of Biologicals, Ministry of Health \& Family Welfare, Noida, Uttar Pradesh, India \\ ${ }^{2}$ Defence Institute of High Altitude Research (DIHAR), DRDO, Ministry of Defence, Leh-Ladakh, Jammu \& \\ Kashmir, India \\ ${ }^{3}$ Department of Medicine, University of Sao Paulo, State of Sao Paulo, Brazil
}

\begin{abstract}
Most vaccines for human and veterinary use are complex biological preparations having one or more antigens along with an adjuvant product to improve the immune response against the specific disease. Conventional vaccines have used numerous animals for production and quality compliance before the release of the final product. Animal based potency tests were required to help in ensuring that each batch of vaccine is consistently safe, pure, potent and effective by providing a level of protection as determined in the original efficacy studies. As a result, the levels of pain and suffering in animals were compromised as compared to other purposes of animal experimentation. Therefore, there is a need to identify viable options to replace these methods of vaccine production and quality check without affecting their quality, potency, and efficacy. This review article will highlight the progress and breakthroughs about the achievements of $3 R s$ (replace, reduce, and refine) principles especially in the development of alternative test models including physio-biochemical, immunochemical and in-vitro methods using so- called "consistency approach" in the area of human and veterinary vaccinology. This article also provides a critical review on the various methods used for potency assays and the factors affecting the accuracy of these methods.
\end{abstract}

Keywords: Potency test, Vaccine, 3Rs.

Accepted on March 4, 2018

\section{Introduction}

Vaccines have been proved a wonderful tool of immunization in modern medicine, which saved more, lives worldwide than any other medical product or procedure in past 50 years. Their importance will further increase in coming the days due to more outbreaks of contagious diseases with varied strain and serotypes. According to literature, history of vaccination can be traced back to ancient Greece as far as 429 BC. The Greek Thucydides noticed that people who survived the smallpox plague in Athens did not become re-infected with the disease. Later on, in $900 \mathrm{AD}$, Chinese were the first to discover and use a primitive form of vaccination called variolation. The aim was to prevented smallpox by exposing healthy people with tissue from the scabs of diseased person. In 1796, a British physician Dr. Edward Jenner discovered vaccination in its modern form and proved to the scientific community that it worked. Subsequently, Royal Jennerian Institute founded in 1803 for the production of the vaccines [1].

Different types of vaccines, classified on the basis of the antigen used in their preparation have been shown in the Table 1 below:

Table 1. Examples of vaccines by types.

S No $\begin{aligned} & \text { Type } \\ & \text { vaccine }\end{aligned} \quad$ of $\begin{aligned} & \text { Method } \\ & \text { Production }\end{aligned}$ of Examples of Vaccines

\begin{tabular}{|c|c|c|c|}
\hline 1 & $\begin{array}{l}\text { Inactivated } \\
\text { (Killed } \\
\text { antigens) }\end{array}$ & $\begin{array}{l}\text { Vaccines containing } \\
\text { killed } \\
\text { microorganisms }\end{array}$ & $\begin{array}{l}\text { Hepatitis A, flu, cholera, plague, } \\
\text { Whole-cell pertussis (wP), } \\
\text { Inactivated polio virus (IPV) }\end{array}$ \\
\hline 2 & $\begin{array}{l}\text { Live } \\
\text { Attenuated } \\
\text { Vaccines } \\
\text { (LAV) }\end{array}$ & $\begin{array}{l}\text { Vaccine contains live } \\
\text { organisms that have } \\
\text { been weakened to } \\
\text { disable their virulent } \\
\text { properties }\end{array}$ & $\begin{array}{l}\text { Oral polio vaccine (OPV), } \\
\text { Measles, Rotavirus, Yellow } \\
\text { fever, rubella, measles, mumps, } \\
\text { typhoid, tuberculosis, Bacillus } \\
\text { Calmette Guerin or BCG }\end{array}$ \\
\hline 3 & $\begin{array}{l}\text { Toxoids } \\
\text { (Inactivated } \\
\text { toxins) }\end{array}$ & $\begin{array}{l}\text { Vaccines containing } \\
\text { inactivated toxic } \\
\text { compounds secreted } \\
\text { by the organisms }\end{array}$ & $\begin{array}{l}\text { Diphtheria toxoid, Tetanus toxoid } \\
\text { (TT) }\end{array}$ \\
\hline 4 & $\begin{array}{l}\text { Subunit } \\
\text { vaccines } \\
\text { (Purified } \\
\text { antigens) }\end{array}$ & $\begin{array}{l}\text { These contain part of } \\
\text { the virus is } \\
\text { responsible for } \\
\text { creating disease }\end{array}$ & $\begin{array}{l}\text { Hepatitis B (Hep B), Human } \\
\text { papillomavirus, Acellular } \\
\text { pertussis (aP), Haemophilus } \\
\text { infuenzae type b (Hib), } \\
\text { Pneumococcal (PCV-7, PCV-10, } \\
\text { PCV-13). }\end{array}$ \\
\hline
\end{tabular}

Potency assay is one of the main methods used for assuring the quality of vaccine which is based on the measurement of one or several parameters that have been shown to be related directly or indirectly with product efficacy (the ability to produce an effective level of protection in the target species) [2]. The quality control tests of vaccines have their roots in the work of $19^{\text {th }}$ century scientists Pasteur, Koch, Behring, and Ehrlich. The multi-dilution test design assay with the use of reference preparation which depended upon $\mathrm{ED}_{50}$ was introduced between 1930s-1950s. Subsequently, the current In-vivo quality control tests for established vaccines have been developed during 1950s-1970s (Kendrick test, NIH, etc.) [3]. 
The main types of potency tests performed by vaccine manufacturers includes in-vitro titration of live organisms), enzyme-linked immunosorbent assays (ELISAs) and in-vivo methods involving immunization of small laboratory animals (e.g., mice, rats \& guinea pigs) followed by challenge with a toxin/virus/bacteria or titration of immune sera to measure the antibody response. For live, attenuated vaccines, in-vitro potency assay is mainly used but it is not commonly used for inactivated vaccines [4]. Since, production of vaccine occurs in batches, there is an obviousness of variation in their characteristics if strict controls are not ensured. Therefore, all the manufacturer and regulatory bodies has duty to formulate quality procedures for potency testing using various in-vivo or in-vitro assays.

The use of "alternative" methods are generally concerned with the Principles of the 3Rs,- Replacement, Reduction, and Refinement-of animal testing, first proposed by the scientists William Russell and Rex Burch in their book 'The Principles of Humane Experimental Technique' (1959). Subsequently, various regulatory bodies encourages the development of alternative methods with appropriate relevance, supporting data and test method validation to reduce, refine and replace the animal use for vaccine potency testing. The present review article will provide a deep insight in the progress and achievements of $3 \mathrm{Rs}$ in the development of alternative test methods along with discussions on the relevant factors that might be responsible for slow progress in the introduction of alternatives particularly test validation and harmonization of Guidelines.

\section{Quality Control of Vaccines}

Some methods in biomedical research and testing are used in the modern era of science without undergoing any major change from their early development onwards. This is well applied to potency measurement, especially in vaccines. A test for potency is one of the required listed tests (21CFR610.10) which shall consist of either in-vitro or in-vivo tests, or both, that have been specifically designed for each product so as to indicate its potency in an adequate manner to satisfy the interpretation of potency given by the definition in $600.3(\mathrm{~s})$. As per 21CFR600.3(s), "potency" is defined as "the specific ability or capacity of the product, as indicated by appropriate laboratory tests or by adequately controlled clinical data obtained through the administration of the product in the manner intended, to affect a given result." [5].

Vaccines are derived from living organisms which can be easily distinguished from chemical pharmaceuticals due to their complex physical, chemical and molecular compositions [6]. This indicates that their characteristics may vary from batch to batch, therefore, each batch is considered to be unique. Moreover, the inherent variability of living organisms, the potential of contamination coming from starting materials and the environment must require strict control measures to ensure product consistency, safety and efficacy of each batch [6].

As per norms, safety, quality, and efficacy of the products are the prime legal responsibility of the manufacturer in the countries where vaccines are manufactured and marketed.
These bodies are responsible for the review of licensing applications, lot release, and monitoring the performance of product. Therefore, details of processes by which the vaccine is produced and tested including the in-process and final product testing are the primary goal of the manufacturer [6]. However, accomplishing this goal depends largely on the quality control tests conducted at various critical steps during the production process and application of Good Manufacturing Practices [7,8].

Previously established concepts and methods of quality control were based on the uniqueness of each individual batch of vaccine. The consistency in the production of vaccine means that each batch of the product is of the same quality and is within the same specifications of the batch which has been shown to be safe and efficacious in human trials or in the target animal species. However, a shift in emphasis away from reliance on final product testing will require the development of a control scheme for each product or product class. Therefore, the development and validation of alternative methods based on the principles of 3Rs for potency testing of vaccines to establish consistency in different batches is crucial and of prime importance before the product moves to international markets [6].

\section{Importance of 3Rs in the Field of Vaccinology}

The potency test is mainly used for quality control evaluation of vaccines based on an immunization-challenge procedure in laboratory animals. Many attempts have been made to modify these animal models to improve its relevance and statistical significance. However, the principle of immunizationchallenge procedure in laboratory animals is still being used in vaccine research and routine lot-release testings. However, these models have proven to be instrumental in scientifically underpinning the correlation between protection of selected vaccine antigens and their efficacy [9]. The quality control evaluations of vaccines require high frequency of tests with large number of laboratory animals. These potency tests are multi-dose models that include a challenge procedure with virulent micro-organisms [10]. As a result, animal suffer substantial pain and distress during the testing period.

Generally, use of laboratory animal can be scientifically justified if the study benefits for public or veterinary health versus distress to animals and costs of experiment. In spite of that, there is a strong feeling in public circles that how the laboratory animals can be replaced, reduced or refined of their use in biomedical research and testing. Although, for the time being, few of the animal models in vaccine research and development are inevitable and irreplaceable, a significant progress has been made in using in-vitro pre-screening tests to evaluate immunological parameters. For a long time, in-vivo potency tests have been used for routine vaccine lot-release and most of the pharmacopeia relied on direct or indirectchallenge procedure in laboratory animals [9].

Major limitations of the challenge model are that the procedure is expensive and time consuming. It usually takes 2 months for results to come. Moreover, most of the vaccines have shelf life of about 2 years and after this test the vaccine reaches market with only 22 months of life. Potency tests have been designed 
to measure the ability of the vaccine to protect against subsequent challenge with the active component responsible for pathogenicity. Besides, use of virulent microorganisms or toxins in in-vivo potency assays poses a potential risk to those working in the laboratory. Furthermore, there is striking evidence that some surrogate models for potency testing poorly predict the efficacy of the vaccine in the target species [11]. Therefore, the routine use of these methods has not resulted in the on time release of effective vaccines. Use of in-vitro methods might limit the use of in-vivo models for quality evaluation of vaccines. Additionally, the animal models have several limitations in respect of their relevance, reliability, costs and moral acceptability.

The 3Rs approach is driven by the scientific limitations of the animal models used in potency test of vaccines. There are few examples like the rabies vaccine potency assay (or NIH test) which has a poor reproducibility and wide confidence intervals [12]. Moreover, these tests have to be repeated to get the valid results. The safety test in quality control of veterinary vaccines is often criticized for its doubtful relevance [13]. In addition, animal use in viral vaccine production is strongly discouraged for safety reasons as the animal cells might be a source for transmission of pathogens. Finally, all alternative approaches have one thing in common that they have ultimately resulted in refinement, reduction or replacement of animals use. Now, there is an increased interest in the development of alternatives to the current in-vivo potency tests. Newer models are mainly based on the use of serology instead of the challenge, use of humane endpoints or in-vitro antigen-quantification tests. This new avenue in the quality control of vaccines is called the "consistency approach" which is state-of-the-art in quality control of the new-generation vaccines. In this promising approach, a set of parameters are used to constitute a product profile [9]. These parameters are monitored throughout production and aim to demonstrate that each new batch of vaccine produced is of a similar quality to a vaccine batch of the same provenance, and is of proven efficacy and safety. The consistency in this new approach relies heavily on the implementation of quality systems, such as good manufacturing practice and quality assurance. Further, this strategy involves demonstrating consistency by using a battery of immunochemical, physicochemical and in-vitro methods [14].

\section{Assessment of the Potency Assay}

The safety and potency assessment are the main tests used during vaccine development. Usually a set of 15-20 assay results have to be made available for making quality control and monitoring chart. Therefore, the availability of fast and reliable methods further benefits the existing vaccines by using in-vitro alternatives for in-vivo safety tests. For example, the use of a PCR based method to measure a virulent poliovirus in oral polio vaccine preventing neuro virulence testing in monkeys [15]. Another example is a very sensitive in-vitro vero cell assay for the detection of residual diphtheria toxin described in the Ph Eur. Monograph [16]. Further, safety of a vaccine is ensured by consistency in production and effective post-marketing surveillance.
The available potency assays can be divided into four different categories: challenge test, toxin neutralizing test, cell-based assays and titration assays. The test of potency for liveattenuated vaccines is generally determined by measurement of the number of viable particles, either by colony counting or by virus titration. The use of quantitative PCR (qPCR) has also appeared to be feasible in some cases instead of performing virus titration [17]. The main advantage of qPCR is that it is faster, accurate and reproducible.

\section{Challenge Test}

The challenge test has been used for decades for the quality testing of vaccines, still inferior products arrive in the market. Therefore, the interest in new approaches is increasing especially for lot release testing. In safety point of view, it is easy to manage the risks in cell culture lab as compared to Animal Facility. Although all procedures can be performed in safety cabinets and animals can be housed in containment systems (e.g., isolators or individually ventilated cages) but the injection of virulent material or manipulation of contaminated animals exposes technicians to additional risks. Moreover, animal testing is also laborious, time consuming and expensive.

As mentioned earlier most of the vaccines have a shelf life of less than 2 years and a routine potency test requires around 8 weeks, which is undesirable. Nowadays, due to strict ethical regulations, specific housing conditions such as barrier systems and ventilation equipments, the maintenance cost of animals are rising. In most western countries, majority of scientific community is inclined towards non-animal experimentations, especially for those experiments which inflicts severe pain and suffering [18]. These tests mainly based on large numbers of animals, usually over 100 animals per test and in the majority of cases, the animals will show severe clinical signs. As a result policy makers often emphasize the development of new methods based on 3 Rs. Apart from the economic and ethical reasons, there are also scientific reasons to overlook animal based potency tests. In rabies vaccine and whole-cell pertussis vaccine, the results have poor intra- and inter laboratory reproducibility, resulting in repeat tests by manufacturers $[19,20]$.

In challenge test, determining an immune response in animal model as a correlate for protection against a disease would facilitate the rational development of an effective vaccine. However, finding such a correlate can be difficult. These animal models only assessed the interactions of the organism with the innate, humoral and cellular immune system. However, it is extremely difficult to develop animal models strictly for human pathogens such as Neisseria meningitis, due to the specificity of a range of surface proteins that interact with the host receptors [21]. One of the critical steps required for developing an animal model is identification of molecules that play important role in attachment of pathogens to host cells.

Further, the potency tests are questioned in a term of their clinical efficacy like in case of tetanus vaccine. Moreover, studies have demonstrated a lack of correlations with efficacy 
in clinical studies [22]. Additionally, some animal models do not mimic the human situation like whole cell pertussis potency testing. In regulatory requirement animals are challenged by the intra-cerebral route and not by the intranasal route, which is the natural port of entry for Bordetella pertussis. Moreover, the potency testing does not provide any information about the effect of booster immunizations or the time interval for weaning of immunity [23].

Transgenic mice expressing human target receptors such as CD46 or CD66 have been developed by using genetic methods and used for measles virus or Neisseria infections [24,25]. In addition, the 'humanized immunodeficient mice', in which human tissue retaining immunological functions is transplanted into mice, can be used. In mice transplanted with human umbilical cord blood CD34+ cells, human immune functions could be reconstructed and studied in the presence of HIV infections [26]. However, the infection induced immune responses (direct challenge procedure) may not always match the protection appeared after vaccination in the laboratory animal model [27].

\section{New version of the in-vivo potency tests}

During 1980's, the animal numbers per vaccine was strictly followed as per monograph of pharmacopeia due to prevailing widespread variation in response of individual animals. In the meantime, many factors especially health status, microbiological status of the animals, skills of the technicians, food quality and overall conditions of the Animal facility have been optimized. As a result, there was a reduction in variation in response of testing animals which further allowed a significant in cutback in number of animals per vaccine dilution which was revealed in many studies [28-30].

Based on the outcome of these studies, the WHO and Ph.Eur. have made a slight modification in traditional classical challenge test. These agencies have revised their guidance by indicating that the number of animals to be used should meet the confidence interval criteria specified. Moreover, a single dose potency approach used for diphtheria and tetanus toxoid vaccine in the monograph of $\mathrm{Ph}$. Eur. in place of multi-dose potency test has been allowed further to reduce the number of animals. If there is consistency in vaccine production, the single dose approach is only an option which indicates that the vaccine under study meets the minimum requirement in $\mathrm{IU} / \mathrm{ml}$ [31].

\section{Humane endpoint and in-vivo potency test}

A humane endpoint is the point at which an experimental animal's pain and/or distress can be terminated, minimized, or reduced by actions such as killing the animal humanely, terminating a painful procedure, or providing treatment to relieve pain and/or distress (CCAC 1998) [32]. Humane endpoint can be realized by replacing crude general endpoints such as death or severe clinical findings with more specific local end without compromising of the scientific outcome of the test. The $3 \mathrm{R}$ methods have been developed for several vaccines that include a nonclinical endpoint, ultimately resulting in the reduction in number of animals and significant decline in pain and distress. An example is the use of serology in potency testing of tetanus and diphtheria toxoid vaccines. Humane endpoint might be considered as the best approach to limit the level and duration for several potency assays in which replacement of animal is not possible [33].

As per regulatory guideline, new batches of vaccines must be tested to ensure that they are safe and can provide protective immunity. In general, the routine testing typically involves immunization of several groups of animals with different dilutions of the vaccines followed by exposure of the animals to the infectious agent of interest. Animals with insufficient protective immunity develop induced infections. Unprotected animals often develop the disease which is frequently lethal. Although regulatory authorities have in the past typically required death as an endpoint for such studies, some authorities now allow the humane killing of moribund animals (USDA1998b) [34].

Now, most of the pharmacopoeias or guidelines on vaccine quality accept the concept of establishing humane endpoints in vaccine potency testing based on the scientific applicability. According to 9 CFR 117.4 (e) (USDA), "test animals that show clinical signs of illness that are due to the test may be treated humanely, destroyed if the illness has progressed to a point when death is certain to occur without therapeutic intervention." [35,36]. Severe clinical signs or death are the endpoint of potency test in most of the pharmacopeia. The object behind humane endpoints is to reduce the time interval of pain and distress an animal have to suffer by killing the animal in an early stage of disease without compromising the scientific objective of the test.

In May 2012, the USDA Center for Veterinary Biologics (CVB) issued guidance on the use of humane endpoints and methods in animal testing of biological products. CVB Notice No. 12-12 includes specific guidance regarding the use of humane endpoints in biological products testings, including the rabies challenge test. These guidelines emphases on the use of the anaesthesia for intra-cerebral inoculation of mice during rabies vaccine testing and encourages the use of analgesics in animal studies and potency testings when it can be shown that the study outcome is not affected [37].

To set the humane endpoints in vaccine potency testing, identification of parameters which are predictive of death or severe clinical signs are required. Generally, two types of humane endpoints based on clinical signs and pathophysiological parameters (body weight and body temperature) are used. The use of humane endpoints during the potency testing of whole cell pertussis vaccine, human inactivated rabies, tetanus, and diphtheria vaccines has been shown in the Table 2 below:

Table 2. Examples of earlier humane endpoint for vaccine potency assays. 
Citation: Suresh K, Mahendra PS, Vijay kB, et al. Quality control of vaccines-A journey from classical approach to 3Rs. Microbiol Curr Res. 2018;2(3):45-61.

\begin{tabular}{|c|c|c|c|c|c|}
\hline $\begin{array}{l}\text { S } \\
\text { No }\end{array}$ & Test & Traditional Methods & $\begin{array}{l}\text { Traditional } \\
\text { observations }\end{array}$ & Earlier humane end point & $\begin{array}{l}\text { Referen } \\
\text { ce }\end{array}$ \\
\hline \multirow[t]{2}{*}{1} & \multirow{2}{*}{$\begin{array}{l}\text { Whole cell } \\
\text { pertussis vaccine } \\
\text { potency testing }\end{array}$} & $\begin{array}{l}\text { Assay in mice uses a virulent challenge by } \\
\text { intracerebral route } 14 \text { days after immunization with a } \\
\text { lethal dose of virulent B pertussis microorganisms. }\end{array}$ & $\begin{array}{l}\text { Piloerection, hunched back } \\
\text { posture, apathy, and } \\
\text { convulsions to moribund } \\
\text { condition and finally death. }\end{array}$ & $\begin{array}{l}\text { Specific decreases in body temperature are } \\
\text { effective early predictors of eventual death } \\
\text { and increased levels of acute phase proteins } \\
\text { resulting from cytokine production during } \\
\text { infections }\end{array}$ & [38] \\
\hline & & $\begin{array}{l}\text { Animals are observed for } 14 \text { days, and the number } \\
\text { of mice per dose group surviving this period is used } \\
\text { for probity analysis and estimation of potency. }\end{array}$ & & $\begin{array}{l}\text { Hind limb paralysis and a decrease in body } \\
\text { temperature to less than } 34.5^{\circ} \mathrm{C} \text {, which are } \\
\text { predictive of impending death for Pertussis- } \\
\text { infected animals, }\end{array}$ & {$[39,40]$} \\
\hline 2 & $\begin{array}{l}\text { Rabies vaccine } \\
\text { testing }\end{array}$ & $\begin{array}{l}\text { The regulatory requirement for a mouse lethality test } \\
\text { with a 14-day survival period to be performed on } \\
\text { each batch of rabies vaccine [39]. }\end{array}$ & $\begin{array}{l}\text { A surrogate endpoint was } \\
\text { established for death }\end{array}$ & $\begin{array}{l}\text { Specific weight loss and the presence of } \\
\text { specific neurological signs, which are } \\
\text { predictive of eventual death in unprotected } \\
\text { rabies-infected mice. }\end{array}$ & {$[40]$} \\
\hline 3 & $\begin{array}{l}\text { Tetanus toxoid } \\
\text { vaccine } \\
\text { (Clostridium tetani) } \\
\text { and tetanus } \\
\text { component in } \\
\text { combined vaccines }\end{array}$ & $\begin{array}{l}\text { Multidilution vaccination challenge on guinea pigs or } \\
\text { mice. }\end{array}$ & $\begin{array}{l}\text { Guinea pig or mouse lethal } \\
\text { challenge test }\end{array}$ & Hind leg paresis & [41] \\
\hline 4 & $\begin{array}{l}\text { Diphtheria } \\
\text { component in } \\
\text { combined vaccines } \\
\text { (Corynebacteri } \\
\text { umdiphtheria) }\end{array}$ & $\begin{array}{l}\text { Multidilution vaccination challenge on guinea pigs } \\
\text { with around } 20 \text { control animals. }\end{array}$ & $\begin{array}{l}\text { Guinea pig lethal challenge } \\
\text { test }\end{array}$ & $\begin{array}{l}\text { Erythema score following intradermal } \\
\text { challenge in guinea pigs }\end{array}$ & {$[42]$} \\
\hline
\end{tabular}

The use of humane endpoint has been widely accepted in most pharmacopeia, still, regulatory authorities in individual countries might adhere to results obtained by the lethal challenge test. There might be several reasons for reluctance. However, the obstacles are very serious in nature. Therefore, the International acceptance of humane endpoints will require harmonization or mutual recognition of test requirements. The motto of the implementation of humane endpoints in vaccine quality control does not result in scientific benefits or economic profits but is a matter of humane care and ethics. Now, it is time for regulatory authorities to play a key role in encouraging implementation of humane endpoints when reviewing manufacturer's submissions for lot release based on lethal challenge end-points.

\section{In-vivo models of Serological Analyses to Refine Animal Use}

A slight modification of the traditional potency assay has been achieved by developing serological assay that measures antibody level or some other aspects of the adaptive immune response instead of direct challenge or in-vivo toxin neutralization. In serological methods the amount of protective antibody produced is measured which serves as an indicator of vaccine potency. The procedure is significantly less severe than challenge methods. Nowadays, most of the vaccines licensed today depend on the induction of serum antibodies for their efficacy. For various pathogens particular levels of antibodies have been identified or suggested that confer protection (see the 'Clinical development' section) [43]. Moreover, antibody responses are easy to measure in ELISA or in newly developed multiplex assays analyzing titers for several antigens simultaneously in very small serum volumes [44-47].

Serological methods for several models like clostridial species, diphtheria, pertussis, rabies and leptospiral are available and even validated in large scale through inter laboratory studies organized by the European Directorate for the Quality of Medicines and HealthCare (EDQM) and, in the case of the tetanus vaccine, in collaboration with the EU European Centre for the Validation of Alternative Methods [48,49]. Ph.Eur. has revised their monographs based on the output of these products and now include serology as an alternative to using the challenge procedure. Examples of serological potency assays as $3 \mathrm{R}$ alternatives have been shown in the Table 3 below:

Table 3. Examples of serological potency assays as $3 R$ alternative.

\begin{tabular}{|c|c|c|c|c|}
\hline S No & Vaccines & Animal Model & Traditional Potency test & Serological ELISA Assay as $3 \mathrm{R}$ alternative \\
\hline 1 & $\begin{array}{l}\text { Tetanus toxoid vaccine and tetanus component } \\
\text { in combined vaccines (Clostridium tetani) }\end{array}$ & Mouse/guinea pig & Lethal/paralytic challenge test & $\begin{array}{l}\text { Single-dilution immunization and serologyb, }{ }^{\mathrm{C}-i n-} \text { - } \\
\left.\text { vitro toxin-binding inhibition (ToBlb, }{ }^{c}\right) \text {, indirect } \\
\text { ELISA }^{b}\end{array}$ \\
\hline 2 & Tetanus and diphtheria & Guinea pig & Serological test & Single dose \\
\hline
\end{tabular}




\begin{tabular}{|c|c|c|c|c|}
\hline 3 & $\begin{array}{l}\text { Diphtheria toxoid vaccine and diphtheria } \\
\text { component in combined vaccines } \\
\text { Corynebacteriumdiphtheriae) }\end{array}$ & $\begin{array}{l}\text { Lethal/intradermal } \\
\text { challenge }\end{array}$ & Guinea pig & $\begin{array}{l}\text { Single-dilution immunization and Serology-ELISA } \\
\text { or Vero Cell Assay }{ }^{b, c}\end{array}$ \\
\hline 4 & 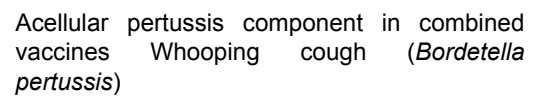 & Mouse & $\begin{array}{l}\text { Multiple-dilution } \\
\text { serologyc }\end{array}$ & Immunization (mice) and serology ${ }^{a, b, c}$ ELISA \\
\hline 5 & Rabies (cell culture, human use) & Mouse & Lethal challenge test & Serology \\
\hline 6 & Erysipelas & Mouse & Lethal challenge test & Serology \\
\hline 7 & Clostridialnovyi (type B)/perfringens/septicum & Rabbit/mouse & Toxin-neutralization test & Serology \\
\hline
\end{tabular}

aAccepted by U.S.regulatory authorities.

bPublished in the European Pharmacopoeia.

'WHO Technical Report Series number and year of publication.

Further, a single-dilution assay can be a valid procedure to demonstrate that a product exceeds the minimal requirement given for potency provided that consistency in production and testing has been proven. Information is presented justifying the use of a single dilution assay based upon quantitative responses for establishing the potency of diphtheria toxoid vaccines. Data of 27 multi-dilution assays on the diphtheria toxoid component of DPT-polio vaccines were retrospectively analysed for consistency in production and testing. Criteria for analysis are given and a protocol for quality assurance of a single dilution assay based upon serology is discussed [50]. However, the use of single dilution assay for the purpose of the batch release is already allowed by WHO. Though, WHO Guidelines should clearly indicate in which circumstances the simplified assay could be used and in which circumstances full assay is required [51].

Besides, Safety, animal welfare (Refine/ reduce), efficiency and test monitoring is very much ensured by ELISA based serological tests if compared to conventional challenge test. In ELISA there is no direct exposure with virulent microorganisms or toxin in the animal facility as well as with experimental animals, therefore the toxin, pain and distress levels in animals have been reduced from severe to minor. Additionally, the performance time is reduced by omitting the observation period and using a quantitative endpoint (antibody titre) which further allow a substantial reduction in the number of animals required per vaccine dose. Moreover, the serology also offers the storage of test samples i.e. serum material that can be reused for questions coming from post-marketing surveillance or for retesting of samples from vaccine manufacturers by regulatory authorities [52].

Nowadays, combination vaccines are receiving importance because of their continued demand for the protection against multiple diseases, especially in children. However, their potency estimates for each of active compound present a unique challenge. For example, potency testing for the DTaP combination vaccine typically requires separate tests for each of the major components (diphtheria, tetanus, and acellular pertussis). Therefore, combining the individual potency procedures into one serological test for multivalent vaccines would have an immediate and significant impact on reducing animal use.

\section{In-vitro Immunological Tests}

Immune response in vertebrate organism is most complex and interactive in nature, involving various cells of the immune system in a cascade of reactions after contact with the antigen. The main determinants in the cascade of reactions are antigen presenting cells (APCs), such as monocytes and dendritic cells, antibody-producing B lymphocytes, helper $\mathrm{T}$ cells, killer $\mathrm{T}$ cells and memory $\mathrm{B}$ and $\mathrm{T}$ cells. These cells are further supported by so-called accessory cells (fibroblast, endothelial cells) as well as cell products such as cytokines and chemokines that play an important role in intercellular communications [52].

Today there are several in-vitro immunogenicity models are available which range from very simple peripheral blood mononuclear cell (PBMC) cultures to complex co-culture systems including various types of immune cells as well as accessory cells. General conceptions about these models are that they hardly mimic the complex immune response, particularly when correlates of protection for specific immune parameters have not yet been established. However, some have shown good correlation between vaccine quality and cytokine profiles such as stimulation of PBMCs with tetanus toxoid [52].

The major limitations of these models are that they represent only a particular phase during the development of the immune response. Moreover, in-vitro conditions (antigen dose, cell density and cell-cell interaction) differ substantially from invivo situation. In these models, primary responses are difficult to measure due to low number of potentially responsive cells. Therefore, these models at present have been of little help for mandatory required quality control of traditional vaccines. However, the importance is continuously increasing in vaccine development studies that focus on studying a particular aspect of the immune response [52].

\section{Antigen Quantification}

Nowadays, some human vaccines do not require the use of animals because in-vitro methods have been developed that quantify the presence of the protective antigen. In-vitro antigen quantification tests are performed either mainly by determining the number of live particles in case of live attenuated bacterial 
Citation: Suresh K, Mahendra PS, Vijay kB, et al. Quality control of vaccines-A journey from classical approach to $3 R$ s. Microbiol Curr Res. 2018;2(3):45-61.

vaccines (e.g., Bacillus Calmette- Guérin, typhoid and cholera) or, in case of live viral vaccines, by virus titration in cell cultures using end points such as plaque formation, cytopathology and indirectly by virus neutralization using virus-specific serological reagents.

These tests are considered as state-of-the-art technique for lotrelease potency testing of live attenuated vaccines or genetically modified live vaccines based on binding of key protective antigens to specific antibodies in an in-vitro immunoassay. At present, these methods represent the most promising in-vitro approaches for the replacement of animals used in vaccine potency testing. But these tests have been successfully implemented (regulatory acceptance) for only a few products. These include hepatitis $\mathrm{A} / \mathrm{B}$ vaccines, inactivated polio vaccine, polysaccharide and polysaccharide conjugate vaccines, and human papillomavirus vaccine as shown in the Table 4 below:

Table 4. Examples of human vaccine potency tests that replace the use of animals.

\begin{tabular}{|c|c|c|c|c|}
\hline S No & Vaccine & Traditional test procedure & In-vitro methods & $\begin{array}{l}\text { References for alternative } \\
\text { methods }\end{array}$ \\
\hline 1 & Hepatitis A vaccine (hepatitis A virus) & Mouse serology & Antigen quantification, & [53] \\
\hline 2 & Hepatitis B vaccine (hepatitis B virus) & Mouse serology & Antigen quantification, & {$[54]$} \\
\hline 3 & Inactivated polio vaccine (poliovirus) & Mouse serology & Antigen quantification, & {$[55,56]$} \\
\hline 4 & Human papillomavirus vaccine & Mouse serology & Antigen quantification, & [4] \\
\hline 5 & $\begin{array}{l}\text { Erysipelothrixrhusiopathiaea } \quad \text { (inactivated) } \\
\text { (swine Erysipelas) }\end{array}$ & Immunization challenge test in mice & $\begin{array}{l}\text { Antigen quantification-in-vitro } \\
\text { ELISA }\end{array}$ & {$[57]$} \\
\hline 6 & $\begin{array}{l}\text { Bovine respiratory viruses (BRV, BVD, } \mathrm{PI} 3 \\
\mathrm{BRSV}) \mathrm{a} \text { (cattle respiratory disease) }\end{array}$ & & $\begin{array}{l}\text { Antigen quantification-in-vitro } \\
\text { ELISA }\end{array}$ & {$[58]$} \\
\hline 7 & $\begin{array}{l}\text { Newcastle disease virus (chicken respiratory } \\
\text { disease) }\end{array}$ & $\begin{array}{l}\text { Immunization challenge in chickens; } \\
\text { serology }\end{array}$ & $\begin{array}{l}\text { Antigen quantification-in-vitro } \\
\text { ELISA or serology }\end{array}$ & {$[59,60]$} \\
\hline
\end{tabular}

a-Published in the European Pharmacopoeia.

b-WHO Technical Report Series It.

c-No mouse test in European Pharmacopoeia.

d-Not for routine lot release (Ph Eur).

e-Traditional method is antigen quantification.

f-Accepted by U.S. regulatory authorities.

Currently, in-vitro antigen quantification methods represent the most promising approaches for the replacement of animals used in vaccine potency testing. However, there are few limitations in antigen quantification test that it only measures antigen quantity which do not necessarily reflect biological activity. Another limitation for potency testing of inactivated vaccines is that most products include an adjuvant product. These adjuvants cause direct interference with assay (e.g., high background, non-parallelism). Therefore, the adjuvant has to be removed before antigen quantification and also need to ensure that the process used for removal of adjuvant does not affect recovery and/or integrity of the antigen, which could interfere with its detection in the assay [4].

\section{High-Performance Liquid Chromatography (HPLC)/Polymerase Chain Reaction (PCR)}

Nowadays, a majority of industries are inclining toward the use of in-vitro assays. Therefore, regulators in certain regions have been concerned with assessing the impact of the adjuvant on serial potency. This can be achieved through a variety of physical and chemical assays, including particle sizing, aluminium concentration, HPLC and through following tightly controlled Good Manufacturing Practices (GMP) in production systems and component specifications. Moreover, HPLC as an additional potential assay method has shown outstanding results for the quantification of the new purified peptide or subunit vaccines. But still there is need for further development and validation of this method.

Another method is quantitative polymerase chain reaction (qPCR) which has been proposed as an alternative to potency assay due to its ability to determine the number of organisms based on the nucleic acid copy number. However, since the qPCR does not measure either the expression or conformation of the target antigen, its use is limited to a potential supportive assay in combination with another assay. However, cell cultures based assays are widely accepted. Therefore, the use of cell culture toxicity as a replacement for mouse in clostridium antitoxin determination has also been proposed [61].

\section{Acheviements of 3Rs methods in Vaccinology}

In general, the development of an alternative method requires a clear understanding of the purpose for which the assay is to be used. Accordingly, it is important to discriminate between testing procedures for development of novel vaccine, the batch quality control of licensed vaccines and fully established products. Generally, it is possible to use tests which are 
different from those used to determine the efficacy of novel formulations for the release of established products. However, these batch release tests should be a subset of those used to characterize the product going into clinical trials. To develop effective and credible alternative methods, it is essential to understand the mechanism of action of vaccine [11].

In vaccines, the relevant and robust assay development generally requires the knowledge of both the mechanism of induction of a protective immune response and the mode of action of the pathogenic entity in causing disease. Moreover, the development of mechanism based assays would also require an understanding of how virulence factors exert their pathogenic effects. Assays developed by following these criteria will lead to the complete replacement of animal models. However, lack of scientific knowledge at present limits the development of such mechanism based assays.

Table 5. Examples of 3Rs achievements for human vaccine potency tests.

\begin{tabular}{|c|c|c|c|c|c|}
\hline $\begin{array}{l}\mathrm{S} \\
\mathrm{N} \\
\mathrm{O}\end{array}$ & Vaccine & Traditional Method & Alternative Method & $3 R$ alternates & $\begin{array}{l}\text { Referen } \\
\text { ce }\end{array}$ \\
\hline 1 & Japanese encephalitis & $\begin{array}{l}\text { mouse immunogenicity assay } \\
\text { followed by a Plaque Reduction } \\
\text { Neutralization (PRN) Test (PRN } \\
\text { Test) }\end{array}$ & $\begin{array}{l}\text { ELISA to determine the } E \text { antigen content of the } \\
\text { Japanese encephalitis virus }\end{array}$ & Replacement & [62] \\
\hline \multirow{2}{*}{2} & \multirow{2}{*}{ Tetanus toxoid vaccines } & \multirow{2}{*}{$\begin{array}{l}\text { Lethal/paralytic challenge test in } \\
\text { the batch potency testing }\end{array}$} & $\begin{array}{l}\text { ELISA procedure for Batch Potency Testing of } \\
\text { Tetanus Vaccines }\end{array}$ & $\begin{array}{l}\text { Reduction (Single-dilution test } \\
\text { instead of multi-dilution), } \\
\text { Refinement (Endpoint is not death) }\end{array}$ & {$[63,64]$} \\
\hline & & & $\begin{array}{l}\text { Toxin Binding Inhibition (ToBI) Test for Batch Potency } \\
\text { Testing of Tetanus Vaccines }\end{array}$ & $\begin{array}{l}\text { Reduction (Single-dilution test } \\
\text { instead of multi-dilution), } \\
\text { Refinement (Endpoint is not death) }\end{array}$ & {$[65,66]$} \\
\hline \multirow{2}{*}{3} & \multirow{2}{*}{ Diphtheria Vaccine } & \multirow{2}{*}{$\begin{array}{l}\text { Lethal/Intradermal Challenge Test } \\
\text { in the Batch Potency Testing of - } \\
\text { Diphtheria Vaccine }\end{array}$} & $\begin{array}{l}\text { ELISA Procedure for Potency testing of Diphtheria } \\
\text { Vaccines }\end{array}$ & Reduction \& Refinement & {$[67]$} \\
\hline & & & $\begin{array}{l}\text { Vero Cell Assay for Potency testing of Diphtheria } \\
\text { Vaccines }\end{array}$ & Reduction \& Refinement & {$[68,69]$} \\
\hline
\end{tabular}

Diphtheria component

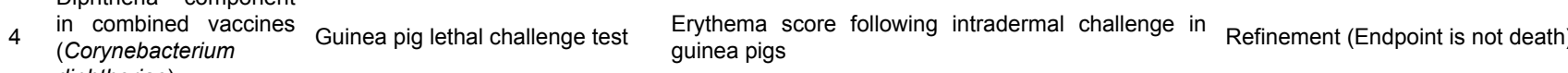

$[70,71]$ diphtheriae)

5 Tetanus and Diphtheria $\begin{aligned} & \text { Combination } \begin{array}{c}\text { Tetanus and } \\ \text { Diphtheria vaccines-separate }\end{array} \\ & \text { vactanus and Diphtheria Serology test-single test for Reduction }\end{aligned}$

\begin{tabular}{|c|c|c|c|c|c|}
\hline 6 & Hepatitis B Vaccine & $\begin{array}{l}\text { Potency Test of Hepatitis B } \\
\text { Vaccine (Mouse) }\end{array}$ & Serological Antigen Quantification & Reduction \& Refinement & [67] \\
\hline 7 & $\begin{array}{l}\text { Inactivated } \\
\text { Poliomyelitis Vaccine }\end{array}$ & $\begin{array}{l}\text { Serological } \quad \text { Potency Test of } \\
\text { Poliomyelitis } \quad \text { (inactivated) } \\
\text { Vaccine (Rat) }\end{array}$ & Antigen quantification & Replacement & {$[67]$} \\
\hline 8 & Rabies Vaccine & $\begin{array}{l}\text { Lethal challenge test for Rabies } \\
\text { Vaccine }\end{array}$ & Single dilution assay & Reduction & {$[67]$} \\
\hline \multirow{4}{*}{9} & \multirow{4}{*}{$\begin{array}{l}\text { Inactivated rabies virus } \\
\text { vaccine }\end{array}$} & \multirow{2}{*}{$\begin{array}{l}\text { Mouse multiple-dilution lethal } \\
\text { challenge test }\end{array}$} & \multicolumn{3}{|l|}{ Convulsions, paralysis, paresis } \\
\hline & & & Humane Endpoints for Rabies Potency Testing & Refinement & {$[67,72]$} \\
\hline & & NIH mouse protection test & $\begin{array}{l}\text { Multi-dose serological assay, based on vaccination of } \\
\text { mice and subsequent determination of neutralizing } \\
\text { antibodies in vitro. }\end{array}$ & $\begin{array}{l}\text { Reduction, } \quad \text { Refinement } \\
\text { Replacement }\end{array}$ & $\&[73]$ \\
\hline & & $\begin{array}{l}\text { In-vivo rabies vaccine potency } \\
\text { test }(\mathrm{NIH} \text { test }\end{array}$ & $\begin{array}{l}\text { Time Resolved Fluoroimmunoassay (TRFIA) for the } \\
\text { assay of rabies virus glycoprotein }\end{array}$ & Replacement & [74] \\
\hline \multirow[b]{2}{*}{10} & \multirow[b]{2}{*}{ Oral Polio Vaccine } & \multirow[b]{2}{*}{$\begin{array}{l}\text { Oral Polio Neurovirulence Test- } \\
\text { (Monkey intra-cerebral) }\end{array}$} & Mutant Analysis by PCR and Restriction Enzyme & Reduction & {$[75,76]$} \\
\hline & & & $\begin{array}{l}\text { Cleavage (MAPREC test) TgPVR21 Mouse } \\
\text { Neurovirulence Test }\end{array}$ & Replacement & [77] \\
\hline 11 & Diptheria Vaccine & $\begin{array}{l}\text { Residual Toxicity in Diptheria } \\
\text { Vaccine (Guinea pig) }\end{array}$ & Vero Cell Test of Diphtheria Toxoid Vaccines & Replacement & [78] \\
\hline 12 & HBsAg Vaccine & $\begin{array}{l}\text { In-vivo method for } \mathrm{HBsAg} \\
\text { potency }\end{array}$ & $\begin{array}{l}\text { In-vitro method for HBsAg content using Auszyme } \\
\text { EIA kit }\end{array}$ & Replacement & [79] \\
\hline
\end{tabular}


Citation: Suresh K, Mahendra PS, Vijay kB, et al. Quality control of vaccines-A journey from classical approach to 3Rs. Microbiol Curr Res. 2018;2(3):45-61.

\begin{tabular}{|c|c|c|c|c|c|}
\hline & & & \\
\hline & & & $\begin{array}{l}\text { In-vitro method for HBsAg content using an in-house- } \\
\text { developed method based upon an inhibition ELISA }\end{array}$ & Replacement & [80-82] \\
\hline 13 & $\begin{array}{l}\text { Anthrax } \quad \text { Vaccine } \\
\text { Adsorbed }\end{array}$ & $\begin{array}{l}\text { In-vivo mouse immunogenicity } \\
\text { test }\end{array}$ & $\begin{array}{l}\text { Toxin neutralization assay (TNA) to measure } \\
\text { antibodies to anthrax Protective Antigen (PA) }\end{array}$ & Replacement & [83] \\
\hline 14 & $\begin{array}{l}\text { Whole cell pertussis } \\
\text { (wP) vaccine }\end{array}$ & Lethal Challenge potency testing & $\begin{array}{l}\text { Two Phase Studies: Evaluation phase and Validation } \\
\text { phase with Humane endpoints }\end{array}$ & Reduction and Refine ment & [84] \\
\hline 15 & $\begin{array}{lr}\text { Acellular } & \text { pertussis } \\
\text { component in combined } \\
\text { vaccines } & \text { Whooping } \\
\text { cough } & \text { (Bordetella } \\
\text { pertussis) } & \end{array}$ & Multiple-dilution mouse serology & Immunization (mice) and Serology ELISA & Replacement & {$[85-87]$} \\
\hline 16 & $\begin{array}{l}\text { Hepatitis A vaccine } \\
\text { (hepatitis A virus) }\end{array}$ & Mouse serology & Antigen quantification & Replacement & {$[88,89]$} \\
\hline 17 & $\begin{array}{l}\text { Inactivated polio } \\
\text { vaccine (poliovirus) }\end{array}$ & Rat serology & Antigen quantification & Replacement & $\begin{array}{l}{[88,90,9} \\
1]\end{array}$ \\
\hline 18 & $\begin{array}{l}\text { Human papillomavirus } \\
\text { vaccine }\end{array}$ & Mouse serology & Antigen quantification & Replacement & [92] \\
\hline 19 & Rotavirus vaccine & In-Vivo potency assays & $\begin{array}{l}\text { Cell-based viral replication followed by quantitative } \\
\text { reverse-transcription polymerase chain reaction (RT- } \\
\text { QPCR) analysis }\end{array}$ & Replacement & [93] \\
\hline 20 & $\begin{array}{l}\text { Live Rubella Virus } \\
\text { Vaccine }\end{array}$ & In-Vivo potency assays & $\begin{array}{l}\text { In-vitro cytopathic effect (CPE) with rabbit kidney } \\
\text { epithelial (RK-13) cell culture }\end{array}$ & Replacement & [94] \\
\hline 21 & Smallpox virus vaccine & $\begin{array}{l}\text { Titration onto chorioallantoic } \\
\text { membranes of fertilized hen eggs } \\
\text { (CAM assay). }\end{array}$ & Vero cell culture titration assay. & Replacement & [95] \\
\hline 22 & $\begin{array}{l}\text { Trivalent, live, measles, } \\
\text { mumps, rubella } \\
\text { vaccines (MMR). }\end{array}$ & CCID50 and plaque assays & Quantitative PCR after cell culture & Replacement & [96] \\
\hline 23 & $\begin{array}{l}\text { Whole cell pertussis } \\
\text { vaccines }\end{array}$ & $\begin{array}{l}\text { Safety: mouse weight gain test. } \\
\text { Potency: Kendrick test-large } \\
\text { numbers of animals, severe } \\
\text { distress, poor precision and } \\
\text { reliability }\end{array}$ & $\begin{array}{l}\text { Respiratory challenge assays, nitric oxide induction } \\
\text { assay and serological assays. }\end{array}$ & Replacement \& Refinement & [97] \\
\hline 24 & $\begin{array}{l}\text { Acellular pertussis } \\
\text { vaccines (ACPVs) }\end{array}$ & $\begin{array}{l}\text { The histamine sensitization test } \\
\text { (HIST) }\end{array}$ & $\begin{array}{l}\text { Combination of enzyme coupled-HPLC (E-HPLC) } \\
\text { and carbohydrate binding assays to examine both the } \\
\text { functional domains of PT. }\end{array}$ & Replacement \& Refinement & [98] \\
\hline 25 & Cholera & $\begin{array}{l}\text { Potency: multidilution vaccination } \\
\text { +serology }\end{array}$ & $\begin{array}{l}\text { Enzyme-linked immunosorbent assay (ELISA) titers } \\
\text { of the antibody secreted in the cell supernatant. }\end{array}$ & Replacement & [99] \\
\hline 26 & $\begin{array}{l}\text { Haemophilus type B } \\
\text { conjugate }\end{array}$ & $\begin{array}{l}\text { Multidilution } \\
\text { +serology }\end{array}$ & $\begin{array}{l}\text { High throughput SBA for anti-Hib antibodies that } \\
\text { would be useful for evaluating various Hib vaccines }\end{array}$ & Replacement \& Refinement & [100] \\
\hline
\end{tabular}

At the moment, there is a paradigm shift in the concept of vaccine quality control from classical to consistency approach. Main emphasis is being put on ensuring the consistency in production of a vaccine and not regarding each batch produced as a unique product. Therefore, the main focus should remain in monitoring of consistency rather than to establish the true effectiveness of a vaccine. The characteristics of a new batch of vaccine should be similar to those of a batch which has been shown to be safe and efficacious [2].

For classical animal tests, many alternative methods for the quality control of vaccines have been developed in last two decades and even they have been implemented successfully.
But in some vaccine products, in-vitro assays will not be able to completely replace animal models but in near future, the potency testing in animals is likely to disappear when current vaccines are replaced by highly purified and well-characterised genetically engineered products. As these new generation vaccines are better defined and allow the use of in-vitro and physico-chemical methods for their quality control, thus using less or no animals for the quality control of batches. The $3 \mathrm{Rs}$ achievement in quality control of vaccine has is shown in Table 5 for human vaccines and Table 6 for veterinary vaccines below:

Table 6. Examples of $3 R$ s achievements for veterinary vaccine potency tests.

\begin{tabular}{lllll}
\hline S No Vaccine & Traditional Method & Alternative Method & 3R alternates \\
\hline
\end{tabular}




\begin{tabular}{|c|c|c|c|c|c|}
\hline 1 & $\begin{array}{l}\text { Inactivated swine erysipelas } \\
\text { vaccines }\end{array}$ & $\begin{array}{l}\text { Lethal challenge test in the } \\
\text { batch potency testing of } \\
\text { inactivated swine erysipelas } \\
\text { vaccines }\end{array}$ & $\begin{array}{l}\text { Serological Method (ELISA) for the Batch } \\
\text { Potency Testing of Inactivated Swine } \\
\text { Erysipelas Vaccines }\end{array}$ & $\begin{array}{l}\text { Reduction \& Refinement } \\
\text { (Endpoint is not death) }\end{array}$ & {$[101,102]$} \\
\hline 2 & Safety Test & Target Animal Safety Test & Deletion of test & Replacement & [103] \\
\hline 3 & $\begin{array}{l}\text { Inactivated rabies virus vaccine } \\
\text { (Lyssavirus rabies) }\end{array}$ & $\begin{array}{l}\text { Study endpoints used were } \\
\text { Moribund condition or death }\end{array}$ & Convulsions, paralysis, paresis & Refinement & [104-106] \\
\hline 4 & $\begin{array}{l}\begin{array}{l}\text { Inactivated swine } \quad \text { erysipelas } \\
\text { vaccine } \\
\text { rhusiopathiae) }\end{array} \\
\text { (Erysipelothrix }\end{array}$ & $\begin{array}{l}\text { Study endpoints used were } \\
\text { Moribund condition or death }\end{array}$ & $\begin{array}{l}\text { Pathognomonic, diamond } \\
\text { erythematous skin lesions, elevated } \\
\text { temperature, arthritis }\end{array}$ & $\begin{array}{l}\text { Reduction \& Refinement } \\
\text { (Endpoint is not death) }\end{array}$ & {$[107-109]$} \\
\hline 5 & Fowlpox virus vaccine & $\begin{array}{l}\text { Study endpoints used were } \\
\text { Moribund condition or death }\end{array}$ & $\begin{array}{l}\text { Pox lesions, warty eruptions/scabs on } \\
\text { combs and wattles }\end{array}$ & $\begin{array}{l}\text { Reduction \& Refinement } \\
\text { (Endpoint is not death) }\end{array}$ & {$[107,110]$} \\
\hline 6 & $\begin{array}{l}\text { Inactivated rabies } \quad \text { vaccine } \\
\text { (Lyssavirus rabies) }\end{array}$ & $\begin{array}{l}\text { Immunization challenge in } \\
\text { mice (intracerebral) }\end{array}$ & $\begin{array}{l}\text { Immunization (mice) and serology: In-vitro } \\
\text { RFFIT (rapid fluorescent focus inhibition } \\
\text { test) }\end{array}$ & Replacement & {$[111-113]$} \\
\hline 7 & $\begin{array}{l}\text { Inactivated swine } \begin{array}{r}\text { erysipelas } \\
\text { vaccine } \\
\text { rhusiopathiae) }\end{array} \\
\text { (Erysipelothrix }\end{array}$ & Mouse lethal challenge test & $\begin{array}{l}\text { Immunization (mice) and serology: In-vitro } \\
\text { antibody quantification-ELISA }\end{array}$ & Replacement & {$[114,115]$} \\
\hline 8 & $\begin{array}{l}\text { Clostridium novyi (Type B); Bovine } \\
\text { (Black disease) }\end{array}$ & $\begin{array}{l}\text { Rabbit immunization/mouse } \\
\text { toxin neutralization test }\end{array}$ & $\begin{array}{l}\text { Immunization (rabbits) and Serology: In-vitro } \\
\text { immunochemical method or neutralization in } \\
\text { cell cultures }\end{array}$ & $\begin{array}{l}\text { Refinement } \\
\text { Replacement }\end{array}$ & {$[116,117]$} \\
\hline 9 & $\begin{array}{l}\text { Clostridium septicum; Bovine } \\
\text { (malignant edema) }\end{array}$ & $\begin{array}{l}\text { Rabbit immunization/mouse } \\
\text { toxin neutralization test }\end{array}$ & $\begin{array}{l}\text { Immunization (rabbits) and serology: In-vitro } \\
\text { immunochemical method or neutralization in } \\
\text { cell cultures }\end{array}$ & $\begin{array}{l}\text { Refinement } \\
\text { Replacement }\end{array}$ & {$[117,118]$} \\
\hline 10 & $\begin{array}{l}\text { Clostridium perfringens } \mathrm{C} / \mathrm{D} ; \\
\text { Bovine (Enterotoxemia) }\end{array}$ & $\begin{array}{l}\text { Rabbit immunization/mouse } \\
\text { TNT }\end{array}$ & $\begin{array}{l}\text { Immunization (rabbits) and serology: In-vitro } \\
\text { immunochemical method or neutralization in } \\
\text { cell cultures }\end{array}$ & $\begin{array}{l}\text { Refinement } \\
\text { Replacement }\end{array}$ & {$[116,117,119]$} \\
\hline 11 & $\begin{array}{l}\text { Tetanus Antitoxin Products } \\
\text { (equine); (Clostridium tetani) }\end{array}$ & $\begin{array}{l}\text { Guinea pig immunization/ } \\
\text { guinea pig toxin-antitoxin } \\
\text { neutralization test }\end{array}$ & $\begin{array}{l}\text { Immunization (guinea pigs) and serology: } \\
\text { In-vitro toxin binding inhibition (TOBI), } \\
\text { indirect ELISA }\end{array}$ & $\begin{array}{l}\text { Refinement } \\
\text { Replacement }\end{array}$ & {$[120,121]$} \\
\hline \multirow{5}{*}{12} & \multirow{2}{*}{$\begin{array}{l}\text { Leptospirainterrogans } \\
\text { Serovarcanicola Bacterin Canine } \\
\text { leptospiral (inactivated, } \\
\text { adjuvanted and non adjuvanted) }\end{array}$} & \multirow{2}{*}{$\begin{array}{l}\text { Immunization challenge test } \\
\text { in hamsters }\end{array}$} & $\begin{array}{l}\text { Immunization (hamsters) and serology: in- } \\
\text { vitro method to determine antibodies }\end{array}$ & $\begin{array}{l}\text { Refinement } \\
\text { Replacement }\end{array}$ & [122] \\
\hline & & & $\begin{array}{l}\text { USDA Supplemental Assay Methods (SAM) } \\
625\end{array}$ & & [123] \\
\hline & $\begin{array}{l}\text { Leptospirakirshnerii } \\
\text { Serovargryppotyphosa }\end{array}$ & & $\begin{array}{l}\text { USDA Supplemental Assay Methods (SAM) } \\
626\end{array}$ & Replacement & {$[124]$} \\
\hline & $\begin{array}{l}\text { Leptospirainterrogans } \\
\text { Serovarpomona }\end{array}$ & & $\begin{array}{l}\text { USDA Supplemental Assay Methods (SAM) } \\
624\end{array}$ & Replacement & [125] \\
\hline & $\begin{array}{l}\text { Leptospirainterrogans } \\
\text { Serovaricterohaemorrhagiae }\end{array}$ & & $\begin{array}{l}\text { USDA Supplemental Assay Methods (SAM) } \\
627\end{array}$ & Replacement & {$[126]$} \\
\hline \multirow[t]{2}{*}{13} & $\begin{array}{l}\text { Leptospirainterrogans } \\
\text { Serovarhardjobacterin E Bovine }\end{array}$ & \multirow{2}{*}{$\begin{array}{ll}\text { Cattle } & \text { immunization } \\
\text { challenge: Immunization } \\
\text { challenge test in hamsters }\end{array}$} & $\begin{array}{l}\text { Immunization (guinea pigs) and serology: } \\
\text { microagglutination test }\end{array}$ & $\begin{array}{l}\text { Refinement } \\
\text { Replacement }\end{array}$ & {$[127]$} \\
\hline & Leptospira hardjo & & $\begin{array}{l}\text { USDA Supplemental Assay Methods (SAM) } \\
624\end{array}$ & & {$[125]$} \\
\hline \multirow[b]{2}{*}{14} & \multirow[b]{2}{*}{$\begin{array}{l}\text { Rabies vaccine } \quad \text { (Lyssavirus } \\
\text { rabies) }\end{array}$} & \multirow[b]{2}{*}{ Multiple-dilution assays } & Single-dilution assay & Reduction & {$[128-130]$} \\
\hline & & & $\begin{array}{l}\text { NIH potency test (Center for Veterinary } \\
\text { Biologics (CVB) intends to eliminate the } \\
\text { upper limit LD50 for a valid challenge when } \\
\text { conducting the Rabies Virus) }\end{array}$ & Reduction & {$[131]$} \\
\hline 15 & Brucellaabortus (cattle brucellosis) & Invivo Potency Assay & $\begin{array}{l}\text { In-vitro titration method determining colony- } \\
\text { forming units (tryptose agar) }\end{array}$ & Replacement & [132] \\
\hline 16 & $\begin{array}{ll}\text { Erysipelothrix } & \text { rhusiopathiae } \\
\text { (swine erysipelas) } & \end{array}$ & $\begin{array}{l}\text { Vaccination challenge test in } \\
\text { swine }\end{array}$ & $\begin{array}{l}\text { In-vitro titration method determining colony- } \\
\text { forming units ( } 5 \% \text { bovine blood agar) }\end{array}$ & Replacement & [133] \\
\hline 17 & $\begin{array}{l}\text { Mannheimiahaemolytica } \\
\text { (Pasteurellahaemolytica) } \\
\text { respiratory disease) }\end{array}$ & $\begin{array}{l}\text { Vaccination challenge test in } \\
\text { cattle }\end{array}$ & $\begin{array}{l}\text { In-vitro titration method determining colony- } \\
\text { forming units (trypticase soy agar) }\end{array}$ & Replacement & [134] \\
\hline
\end{tabular}


Citation: Suresh K, Mahendra PS, Vijay kB, et al. Quality control of vaccines-A journey from classical approach to 3Rs. Microbiol Curr Res. 2018;2(3):45-61.

\begin{tabular}{|c|c|c|c|c|c|}
\hline 18 & $\begin{array}{l}\text { Chlamydophilafelis } \\
\text { respiratory disease) }\end{array}$ & In-vivo Potency Assay & $\begin{array}{l}\text { Cell culture-in-vitro titration method utilizing } \\
\text { indirect fluorescent antibody staining } \\
\text { (mouse fibroblasts; MEM) }\end{array}$ & Replacement & [135] \\
\hline 19 & $\begin{array}{l}\text { Feline calicivirus (feline respiratory } \\
\text { disease) }\end{array}$ & In-vivo Potency Assay & $\begin{array}{l}\text { Cell culture-in-vitro titration method utilizing } \\
\text { plaque-forming units (Crandall feline kidney } \\
\text { cells; MEM) }\end{array}$ & Replacement & [136] \\
\hline 20 & $\begin{array}{l}\text { Feline Rhinotracheitis Virus (feline } \\
\text { respiratory disease) }\end{array}$ & In-vivo Potency Assay & $\begin{array}{l}\text { Cell culture-in-vitro titration method utilizing } \\
\text { plaque-forming units (Crandall feline kidney } \\
\text { cells; MEM) }\end{array}$ & Replacement & [137] \\
\hline 21 & $\begin{array}{l}\text { Mareks disease virus (poultry } \\
\text { neoplastic disease) }\end{array}$ & $\begin{array}{l}\text { Vaccination challenge test in } \\
\text { chickens }\end{array}$ & $\begin{array}{l}\text { Cell culture-in-vitro titration method (primary } \\
\text { chick embryo fibroblasts; M199) }\end{array}$ & Replacement & [138] \\
\hline 22 & \begin{tabular}{lrr} 
Porcine & \multicolumn{2}{c}{ transmissible } \\
gastroenteritis & caused & by \\
coronavirus & TGEV & (swine \\
infectious diarrhea) &
\end{tabular} & In-vivo Potency Assay & $\begin{array}{l}\text { Cell culture-in-vitro titration method utilizing } \\
\text { cytopathic effect (swine testicular cells; } \\
\text { MEM) }\end{array}$ & Replacement & [139] \\
\hline 23 & $\begin{array}{l}\text { Porcine rotavirus (swine infectious } \\
\text { diarrhea) }\end{array}$ & In-vivo Potency Assay & $\begin{array}{l}\text { Cell culture--in-vitro method utilizing } \\
\text { cytopathic effect or indirect fluorescent } \\
\text { antibody technique (Rhesus monkey kidney } \\
\text { cells; MEM) }\end{array}$ & Replacement & [140] \\
\hline 24 & $\begin{array}{l}\text { Infectious canine hepatitis caused } \\
\text { by canine adenovirus Type } 1 \\
\text { (canine hepatitis) }\end{array}$ & In-vivo Potency Assay & $\begin{array}{l}\text { Cell culture-in-vitro method utilizing } \\
\text { cytopathic effect (primary dog kidney cells; } \\
\text { MEM) }\end{array}$ & Replacement & [141] \\
\hline 25 & $\begin{array}{l}\text { Canine distemper virus (canine } \\
\text { viral disease) }\end{array}$ & In-vivo Potency Assay & $\begin{array}{l}\text { Cell culture-in-vitro method utilizing } \\
\text { cytopathic effect (Vero cells; MEM) }\end{array}$ & Replacement & [142] \\
\hline 26 & $\begin{array}{l}\text { Infectious bursal disease virus } \\
\text { (IBDV) } \\
\text { immunosuppressive disease) }\end{array}$ & $\begin{array}{l}\text { Immunization challenge test } \\
\text { in chickens }\end{array}$ & $\begin{array}{l}\text { Cell culture-in-vitro titration method of tissue } \\
\text { culture adapted IBDV (primary chick embryo } \\
\text { FB; M199/F10) }\end{array}$ & Replacement & [143] \\
\hline 27 & $\begin{array}{l}\text { Feline panleukopenia caused by } \\
\text { feline parvovirus (feline viral } \\
\text { disease) }\end{array}$ & In-vivo Potency Assay & $\begin{array}{l}\text { Cell culture in-vitro titration method utilizing } \\
\text { indirect fluorescent antibody straining } \\
\text { (Crandall feline kidney cells; MEM) }\end{array}$ & Replacement & [144] \\
\hline 28 & $\begin{array}{l}\text { Mink distemper virus (mink viral } \\
\text { disease) }\end{array}$ & $\begin{array}{l}\text { Immunization challenge test } \\
\text { in mink }\end{array}$ & $\begin{array}{l}\text { Embryonated chicken eggs-titration of viral } \\
\text { plaques on chorioallantoic membrane } \\
\text { (CAM) }\end{array}$ & Replacement & [145] \\
\hline 29 & $\begin{array}{l}\text { Erysipelothrix rhusiopathiae } \\
\text { (inactivated) (swine Erysipelas) }\end{array}$ & $\begin{array}{l}\text { Immunization challenge test } \\
\text { in mice }\end{array}$ & Antigen quantification-in-vitro ELISA & Replacement & [146] \\
\hline 30 & $\begin{array}{l}\text { Bovine respiratory viruses (BRV, } \\
\text { BVD, PI, BRSV) (cattle respiratory } \\
\text { disease) }\end{array}$ & In-vivo Potency Assay & Antigen quantification-in-vitro ELISA & Replacement & [147] \\
\hline 31 & $\begin{array}{l}\text { Newcastle disease virus (chicken } \\
\text { respiratory disease) }\end{array}$ & $\begin{array}{l}\text { Immunization challenge in } \\
\text { chickens; serology }\end{array}$ & $\begin{array}{l}\text { Antigen quantification-in-vitro ELISA or } \\
\text { serology }\end{array}$ & Replacement & {$[148,149]$} \\
\hline 32 & $\begin{array}{l}\text { Tuberculin, PPD Bovis, Intra- } \\
\text { dermic }\end{array}$ & $\begin{array}{l}43 \text { guinea pigs are needed: } \\
20 \text { sensitized to M. avium, } 20 \\
\text { sensitized to } M \text {. bovis, and } 3 \\
\text { non-sensitized to be used as } \\
\text { controls. }\end{array}$ & $\begin{array}{l}\text { The alternate testing protocol uses only } 15 \\
\text { guinea pigs, eliminates the M. avium } \\
\text { sensitized guinea pigs, reduces the number } \\
\text { of PPD dilutions for the test, and uses } 6 \\
\text { injections per guinea pig. }\end{array}$ & Reduction & [150] \\
\hline 33 & Botulism neurotoxin products & $\begin{array}{l}\text { Mouse LD50 Assay for } \\
\text { Botulinum Toxin Testing }\end{array}$ & $\begin{array}{l}\text { Acceptance of cell based assay for Botulism } \\
\text { neurotoxin products }\end{array}$ & $\begin{array}{l}\text { Refine, Reduce and } \\
\text { Replace }\end{array}$ & [151] \\
\hline \multirow[t]{2}{*}{34} & \multirow[t]{2}{*}{ Inactivated influenza vaccines } & \multirow{2}{*}{$\begin{array}{l}\text { Single radial immunodiffusion } \\
\text { (SRID) assay }\end{array}$} & $\begin{array}{l}\text { Monoclonal antibody (mAb)-based potency } \\
\text { assays }\end{array}$ & Refinement & [152] \\
\hline & & & New VaxArray® potency reagent kit & Refinement & [153] \\
\hline
\end{tabular}

\section{Conclusion}

In conclusion, there is a need for rigorous in-process quality control monitoring than the end batch testing. Remarkable advancements have been made in the development, maintenance, and upgradation of in-vitro potency assays like ELISA, Cell culture, SDS-PAGE, 2-D gel electrophoresis, Serology, etc. which minimize the animal use and suffering. However, many hindrances are still encountered in the implementation of 3Rs principles for vaccine potency assays due to their unique compositions, multivalency, and long life cycles. Therefore, relentless research work is required by both health industries and regulatory agencies for the development and validation of robust 3Rs methods at the global scenario.

Other prevailing challenges in the implementation of $3 \mathrm{Rs}$ principles are the lack of comprehensive harmonization of regulatory requirements, cooperation by health authorities to 
accept deviations from established guidelines and strong incentive to develop and implement alternatives of animal testings valid for global regulations. All the alternative methods data should be validated with the in-vivo methods for comparison and thereafter should be included in the guidelines for quality control. Many countries are still using the traditional methods due to lack of mutual acceptance of data (MAD) between the regulatory agencies. If these advanced validated methods are strictly applied at the global level within the time-bound framework by the regulatory agencies, this might be helpful in reducing the numbers as well as the unwanted suffering inflicted to animals during the potency assays.

\section{References}

1. Kripalni A. Histotorical aspect of vaccine. Int $\mathrm{J}$ of Gyanecol and Obst. 2016;2:1-1.

2. Hendriksen C.Validation of Alternative Methods for the Potency Testing of Vaccines. ATLA. 1998;26:747-61.

3. Uhlrich S. 3Rs in Quality control of vaccines for human use: opportunities and barriers Alternatives and Animal Use in the Life Sciences. Sanofi Pasteur Asian congress, Karatsu, Saga, Japan. 2016.

4. Richard MF, Daniela V, Warren C, et al. Non-animal replacement methods for human vaccine potency testing: state of the science and future directions. Procedia in Vaccinol. 2011;5:16-32.

5. Code of Federal regulations. Title-21 Food and Drugs, Chapter I, Subchapter F \& G. 600-799.

6. WHO updates on Regulation and quality control of vaccines. Biologicals. 2017.

7. Guidelines for national authorities on quality assurance for biological products. Geneva, Switzerland: WHO. 1992;31:44.

8. General introduction. In Manual of Laboratory Methods for Potency Testing of Vaccines Used in the WHO Expanded Programme on Immunisation. Geneva, Switzerland: WHO. 1997;3-12.

9. Hendriksen C. Replacement, reduction and refinement alternatives to animal use in vaccine potency measurement. Expert Review of Vaccines. 2014;8:313-22.

10. Hendriksen C. Three Rs achievements in vaccinology. AATEX. 2007;14:575-9.

11. Hendriksen CFM, Garthoff B, Aggerbeck $H$, et al. Alternatives to animal testing in the quality control of immunobiologicals: current status and future prospects. ATLA. 1994;22:420-34.

12. Bruckner. Three $\mathrm{R}$ approaches in the quality control of inactivated rabies vaccines.. ATLA. 2003;31:429-54.

13. AGAATI. The target animal safety test-Is it still relevant? Biologicals. 2002;30:277-88.

14. Metz B, Brunel F, Chamberlin C, et al. The potential of physico-chemical and immunochemical assays to replace animal tests in the quality control of toxoid vaccines. ATLA. 2007;35:323-31.
15. Lu Z, Douthitt MP, Taffs RE, et al. Quantitative aspects of the mutant analysis by $\mathrm{PCR}$ and restriction enzyme cleavage (MAPREC). PCR Methods Appl. 1993;3:176-80.

16. Diphtheria vaccine (adsorbed). In Monograph 0443. Eur Pharmacopeia Commission (5th Ed). 2005;660-1.

17. Schalk JA, de Vries CG, Jongen PM. Potency estimation of measles, mumps and rubella trivalent vaccines with quantitative PCR infectivity assay. Biologicals. 2005;33:71-9.

18. Aldhous P, Coghlan A, Copley J. Let the people speak. New Scientist.1999;22:26-31.

19. Russell WMS, Burch RL. Principles of Humane Experimental Technique. Methuen, London, UK. 1959.

20. Bruckner L, Cussler K, Halder M, et al. Three Rs approaches in the quality control of inactivated rabies vaccines. ATLA.2003;31:429-54.

21. Gorringe AR, Reddin KM, Funnell SG, et al. Experimental disease models for the assessment of meningococcal vaccines. Vaccine. 2005;23:2214-7.

22. Relyveld E, Bengounia A, Huet M, et al. Antibody response of pregnant women to two different adsorbed tetanus toxoids. Vaccine. 1991;9:369-72.

23. Kreeftenberg JG. Report of an informal meeting about alternative methods for the potency control of the diphtheria and tetanus components in vaccines. Dev Biol Stand. 1986; 65:261-6.

24. Mrkic B, Pavlovic J, Rulicke T et al. Measles virus spread and pathogenesis in genetically modified mice. $\mathrm{J}$ Virol. 1998;72:7420-7.

25. Johansson L, Rytkonen A, Bergman P, et al. CD46 in meningococcal disease. Sci. 2003;301:373-5.

26. Nomura T, Tamaoki N, Takakura A, et al. Basic concept of development and practical application of animal models for human diseases. Curr Top Microbiol Immunol. 2008;324:1-24.

27. Plotkin SA. Vaccines: correlates of vaccine-induced immunity. Clin Infect Dis. 2008;47:401-9.

28. Stainer DW, Jakus CM, Sparkus JD. Reduction in animal usage for potency testing of diphtheria and tetanus toxoids. Develop Biol Stand. 1986;65:241-4.

29. Knight PA, Roberts PAG. Studies on the minimal number of animals required to achieve assurance of satisfactory potency in diphtheria and tetanus vaccines. Develop Biol Stand. 1986;65:245-55.

30. Hendriksen CFM, Gun van der JW, Marsman FR, et al. The effects of reductions in the numbers of animals used for the potency assay of the diphtheria and tetanus components of adsorbed vaccines by the methods of the European Pharmacopoeia. J Biol Stand. 1987;15:353-62.

31. Winsnes R, Hendriksen C, Sesardic D, et al. Serological assays as alternatives to the Ph.Eur. challenge test for batch release of tetanus vaccines for humanuse. Dev Biol Stand. 1999; 101:277-88.

32. The CCAC guidelines on: choosing an appropriate endpoint in experiments using animals for research, teaching and testing. 1998. 
Citation: Suresh K, Mahendra PS, Vijay kB, et al. Quality control of vaccines-A journey from classical approach to 3 Rs. Microbiol Curr Res. 2018;2(3):45-61.

33. Hendriksen CFM, Steen B. Refinement of Vaccine Potency Testing with the Use of Humane Endpoints. LAR Journal.2000;41:105-13.

34. William S. Humane Endpoints for Laboratory Animals Used in Regulatory Testing. ILAR Journal. 2002;43:31-8.

35. Code of Federal regulations. Title-9 Animals and Animal products, Chapter I, Subchapter E, Part 117, Section 117.4-Test animals.

36. USDA, Animal Welfare. Final Rules: CFR, Title 9, Animals and Animal Products, Part 117 Animals at Licensed Establishments, 117.4 (e)-Test animals Animals and Animal Products. 1998;813.

37. USDA, Centre for Veterinary Biologics. 2012.

38. Olfert ED, Godson DL. Humane endpoints for infectious disease animal models. ILAR J. 2000;41:99-104.

39. Calver G, Gavieres J, Shakarchi N, et al. Enhancing laboratory animal well-being through refinement by establishing non-lethal endpoints in regulatory assays of certain biologicals. (Abstract). ATLA. 2000;27:373.

40. Cussler K, Morton DB, Hendriksen CFM. Possibilities for the use of humane endpoints in vaccine potency tests. In: Balls M, van Zeller AM, Haider M, eds. Progress in the Reduction, Refinement, and Replacement of Animal Experimentation. Elsevier. 2000;915-27.

41. Hendriksen CFM, Woltjes J, Akkermans AM, et al. Interlaboratory validation of in vitro serological assay systems to assess the potency of tetanus toxoid invaccines for veterinary use. Biologicals. 1994;22:257-68.

42. Validation of an alternative method to animal challenge assay for diptheria vaccine: outcome of a collaborative study. Pharmeuropa, Special issue, Bio. 1996-2.

43. Plotkin SA. Vaccines: correlates of vaccine-induced immunity. Clin Infect Dis. 2008;47:401-9.

44. Lal G, Balmer P, Joseph H, et al. Development and evaluation of a tetraplex flow cytometric assay for quantitation of serum antibodies to Neisseria meningitidissero groups A, C, Y, and W-135. Clin Diagn Lab Immunol. 2004;11:272-9.

45. Lal G, Balmer P, Stanford E, et al. Development and validation of a non aplex assay for the simultaneous quantitation of antibodies to nine Streptococcus pneumoniae serotypes. J Immunol Methods. 2005;296:135-47.

46. Smith JF, Kowalski R, Esser MT, et al. Evolution of typespecific immunoassays to evaluate the functional immune response to Gardasil: a vaccine for human papillomavirus types 16, 18, 6 and 11. Hum Vaccin. 2008;4:134-42.

47. van Gageldonk PG, van Schaijk FG, van der Klis FR, et al. Development and validation of a multiplex immunoassay serum antibodies to Bordetella pertussis, diphtheria and tetanus. J Immunol Methods. 2008;335:79-89.

48. Winsnes R, Hendriksen C. Collaborativestudy for the validation of serological methods for potency testing of tetanus toxoid vaccines for human use. Pharmeuropa Spec Issue Bio. 2001;2000:1-92.

49. Winsnes R, Sesardic D, Daas A, et al. Collaborative study for the validation of serological methods for potency testing of diphtheria toxoid vaccines-part 1. Pharmeuropa Bio. 2004;2: 35-68.

50. Akkermans AM, Hendriksen CFM, Marsman FR, et al. Evaluation and validation of a single-dilution potency assay based upon serology of vaccines containing diphtheria toxoid: analysis for consistency in production and testing at the laboratory of the Control of Biological Products of the RIVM. RIVM Report 172203001. 1993.

51. WHO consultation on DT potency assay and consistency measurement. 2002.

52. Hendriksen CFM. Replacement, reduction and refinementalternatives to animal use in vaccine potency measurement Expert Rev. Vaccines. 2008;8:30.

53. European Pharmacopoeia. Monograph 1935. Hepatitis A Vaccine Inactivated, $\mathrm{Ph}$ Eur. 6th Edition. Strasbourg, France: European Department for the Quality of Medicines within the Council of Europe. 2008.

54. European Pharmacopoeia. Monograph 1056. Hepatitis B Vaccine rDNA, Ph Eur. 6th Edition. Strasbourg, France: European Department for the Quality of Medicines within the Council of Europe. 2008.

55. Method of Analysis. Biological assays: Assay of hepatitis $B$ vaccine (rDNA) [ch. 2.7.15]. In: European Pharmacopoeia, 67th ed.Strasbourg, France: European Department for the Quality of Medicines \& HealthCare (EDQM), Council of Europe. 2011.

56. World Health Organization. Requirements for Hepatitis B Vaccine Inactivated. In: WHO Expert Committee on Biological Standardization. Forty-eighth report. Geneva, World Health Organization, (WHO Technical Report Series No. 889). 1999.

57. United States Department of Agriculture, Center for Veterinary Biologics, Code of Federal Regulations, Title 9, Animals and Animal Products. Part 113- Standard Requirements. Section 113.119. SAM 613: Supplemental Assay Method for In vitro Potency Testing of Erysipelothrix rhusiopathiae Bacterins. 2009. http:// www.aphis.usda.gov/animal_health/vet_biologics/ vb_sams_600_series.shtml

58. United States Department of Agriculture, Center for Veterinary Biologics, Code of Federal Regulations, Title 9, Animals and Animal Products. Part 113- Standard Requirements. SAM 120: Supplemental Assay Method for the in vitro Potency Assay of Bovine Respiratory Viruses in Killed Vaccines. 1991. http:/www.aphis.usda.gov/ animal_health/vet_biologics/vb_sams_100_series.shtml

59. European Pharmacopoeia. Monograph 01/2008:0870. Newcastle Disease Vaccine (Inactivated). Strasbourg, France: EuropeanDepartment for the Quality of Medicines within the Council of Europe. 2008.

60. Claassen I, Maas R, Oei H, et al. Validation study to evaluate the reproducibility of a candidate in vitro potency assay of Newcastle disease vaccines and to establish the suitability of a candidate biological reference preparation. Pharmeuropa Bio. 2004;1:1-15

61. Draayer H. Overview of currently approved veterinary vaccine potency testing methods and methods in 
development that do not require animal use. Procedia in Vaccinology. 2011;5:171-4.

62. Kim BC, Kim DK, Kim HJ, et al. A collaborative study of an alternative in vitro potency assay for the Japanese encephalitis vaccine. Virus Res. 2016;223:190-6.

63. Council of Europe 2.7.8 Assay of Tetanus vaccine (adsorbed). European Pharmacopoeia. 2003.

64. ECVAM, ESAC Statement on the Application of the ELISA Procedure for Batch Potency Testing of Tetanus Vaccines for Human Use. 2002.

65. ECVAM, ESAC Statement on the Application of the ToBI Test for Batch Potency Testing of Tetanus Vaccines for Human Use. 2000.

66. NICEATM-ICCVAM (2012) Alternative Methods for Vaccine Testing, Serology Test for Batch Potency Testing of Human Tetanus Vaccines.

67. Council of Europe (CE), 2.7.6 Assay of Diphtheria vaccine (adsorbed). In: European Pharmacopoeia, 6th ed. Strasbourg, France: CE. 2008.

68. Winsnes R, Sesardic D, Daas A, et al. Collaborative study for the validation of serological methods for potency testing of diphtheria toxoid vaccines-part 1. Pharmeuropa Bio. 2004;2:35-68.

69. Winsnes R, Sesardic D, Daas A. et al. Collaborative study for the validation of serological methods for potency testing of diphtheria toxoid vaccines-part 2. Pharmeuropa Bio. 2006;1:73-88.

70. World Health Organization. Recommendations for diphtheria, tetanus, pertussis and combined vaccines (Amendments 2003). In: WHO Expert Committee on Biological Standardization. Fifty-fourth report. Geneva, World Health Organization, (WHO Technical Report Series No. 927). 2005.

71. European Pharmacopoeia. Monograph 20706. Assay of diphtheria vaccine (adsorbed), Ph.Eur. 6th Edition. Strasbourg, France: European Department for the Quality of Medicines within the Council of Europe. 2008.

72. Office of the Federal Register (U.S.) Title 9 - Animals and Animal Products, Pt.1-199. In: Code of Federal Regulations (C.F.R.), Revised as of January 1. 2009.

73. WHO Drug Information. 2017;31:1

74. Lin G. A time-resolved fluoroimmunoassay to assay the rabies virus glycoprotein: application for estimation of human rabies vaccine potency. Scientific Reports 7, Article number: 7288. 2017.

75. WHO Expert Committee on Biological Standardisation. Forty-eighth Report, WHO Technical Report Series, No. 889. Geneva, Switzerland: World Health Organization (WHO). 1999.

76. Final Report: IABS Scientific Workshop on Neurovirulence Tests of Live Virus Vaccines. Geneva, Switzerland: World Health Organization (WHO). 2005.

77. Dragunsky E, Nomura T, Karpinski K, et al. Transgenic mice as an alternative to monkeys for neurovirulence testing of live oral poliovirus vaccine: validation by a WHO collaborative study. Bulletin of the World Health Organization. 2003;81:251-60.
78. Council of Europe (CE). Absence of toxin and irreversibility of toxoid-Diphtheria vaccine (adsorbed). In: European Pharmacopoeia, 6th ed. Strasbourg, France: CE. 2008.

79. Method of Analysis. Biological assays: Assay of hepatitis $B$ vaccine (rDNA) [ch. 2.7.15]. In: European Pharmacopoeia, 67th ed. Strasbourg, France: European Department for the Quality of Medicines \& HealthCare (EDQM), Council of Europe. 2011.

80. European Pharmacopoeia. Monograph 1056. Hepatitis B vaccine (rDNA), Ph.Eur.6th Edition. Strasbourg, France: European Department for the Quality of Medicines within the Council of Europe. 2008.

81. Giffroy D, Mazy C, Duchêne M. Validation of a new ELISA method for in vitro potency assay of hepatitis Bcontaining vaccines. Pharmeuropa Bio. 2006;1:7-14.

82. Descamps J, Mary A, Rommel E, et al. Release potency tests of hepatitis vaccines. In: Sesardic D, Brown F, Hendriksen CFM, editors. Alternatives to Animals in the Development and Control of Biological Products for Human and Veterinary Use.Meeting of the International Association of Biological Standardization. September 1998. London. Dev Biol Stand. 1999;100:289-94.

83. Juan LA, Rocío IDC. Development and validation of serological methods for human vaccine potency testing: case study of an anthrax vaccine. Procedia in Vaccinology. 2011;5: 213-20.

84. Coenraad FMH. Humane endpoints in vaccine potency testing. Procedia in Vaccinology. 2011;5:221-6.

85. European Pharmacopoeia. Monograph 1356. Pertussis Vaccine Acellular Component, Absorbed, Ph.Eur.6th Edition. Strasbourg, France: European Department for the Quality of Medicines within the Council of Europe. 2008.

86. European Pharmacopoeia. Monograph 1595. Pertussis Vaccine Acellular, Copurified, Absorbed, Ph.Eur. 6th Edition. Strasbourg, France: European Department for the Quality of Medicines within the Council of Europe. 2008.

87. Japanese Minimum Requirements for Biological Products. National Institute of Infectious Diseases, Japan. 2006.

88. European Pharmacopoeia. Monograph 20701.Immunochemical methods, Ph.Eur. 6th Edition. Strasbourg, France: European Department for the Quality of Medicines within the Council of Europe. 2008.

89. World Health Organization. Requirements for Hepatitis A Vaccine Inactivated. In: WHO Expert Committee on Biological Standardization. Forty-fifth report. Geneva, World Health Organization. 1995.

90. European Pharmacopoeia. Monograph 214. Poliomyelitis Vaccine Inactivated, Ph.Eur. 6th Edition. Strasbourg, France: European Department for the Quality of Medicines within the Council of Europe. 2008.

91. World Health Organization. Requirements for Oral Poliomyelitis Vaccine. In: WHO Expert Committee on Biological Standardization. Fifty-first report. Geneva, World Health Organization. 2002.

92. Shank-Retzlaff M, Wang F, Morley T, et al. Correlation between Mouse Potency and In Vitro Relative Potency for 
Citation: Suresh K, Mahendra PS, Vijay kB, et al. Quality control of vaccines-A journey from classical approach to $3 R$ s. Microbiol Curr Res. 2018;2(3):45-61.

Human Papillomavirus Type 16 Virus-Like Particles and Gardasil ® Vaccine Samples. Human Vaccines. 2005;1:191-7.

93. Ranheim 1, Mathis PK, Joelsson DB, et al. Development and application of a quantitative RT-PCR potency assay for a pentavalent rotavirus vaccine (RotaTeq). J Virol Methods. 2006;131:193-201.

94. Der-Yuan W, Sheng-Yen Y, Ching-Pang C, et al. Evaluation and Validation of Potency Testing Method for Live Rubella Virus Vaccine. J Food Drug Anal. 2001:9:183-90.

95. Leparc-GI, Poirier B, El Zaouk A, et al. New generation of cell culture assay for smallpox vaccine potency. J Clin Microbiol. 2003;41:3687-9.

96. Schalk J, de Vries C, Jongen P. Potency estimation of measles, mumps and rubella trivalent vaccines with quantitative PCR infectivity assay. Biologicals. 2005;33:71-9.

97. Xing D, Markey K, Das RG, et al. Whole-cell pertussis vaccine potency assays: the Kendrick test and alternative assays. Expert Rev Vaccines. 2014;13:1175-82.

98. Xing D, Yuen CT, Asokanathan C, et al. Evaluation of an in vitro assay system as a potential alternative to current histamine sensitization test for acellular pertussis vaccines. Biologicals. 2012;40:456-65.

99. Sunny Chang H, David AS. Development of a Novel In Vitro Assay (ALS Assay) for Evaluation of VaccineInduced Antibody Secretion from Circulating Mucosal Lymphocytes. Clin Vaccine Immunol. 2001;8:482-8.

100.Han WK, Kyung HK, JiHye K, et al. A high throughput serum bactericidal assay for antibodies to Haemophilusinfluenzae type b. BMC Infect Dis. 2016;16:473.

101.ECVAM, ESAC Statement on the Validity of a Serological Method (ELISA) for the Batch Potency Testing of Inactivated Swine Erysipelas Vaccines. 2002.

102.Rosskopf SU, Johannes S, Wilhelm M, et al. Quality control of inactivated erysipelas vaccines: Results of an international collaborative study to establish a new regulatory test. Vaccine. 2000;19:1477-83.

103.ECVAM, ESAC Statement on the Relevance of the Target Animal Safety Test for Batch Safety Testing of Vaccines for Veterinary Use. 2002.

104.United States Department of Agriculture, Center for Veterinary Biologics, Code of Federal Regulations, Title 9, Animals and Animal Products. Part 113-Standard Requirements. Section 113.209.SAM 308: Supplemental Assay Method for Potency Testing of Inactivated Rabies Vaccines in Mice Using the National Institutes of Health Test. 2007.

105.European Pharmacopoeia. Monograph 01/2010:0451. Rabies Vaccine (Inactivated) for Veterinary Use. 7th ed. Strasbourg, France:European Department for the Quality of Medicines within the Council of Europe. 2010.

106. Wunderli PS, Dreesen DW, Miller TJ, et al. The rabies peripheral challenge test: more accurate determination of vaccine potency. Vaccine. 2006;24:7115-23.
107. Srinivas G. Refinement alternatives for veterinary vaccine potency testing: overview of currently approved serological methods. Presented at: International Workshop on Alternative Methods to Reduce, Refine, and Replace the Use of Animals in Vaccine Potency and Safety Testing: State of the Science and Future Directions. NICEAM. Bethesda. 2010.

108.Johannes S, Hartinger J, Hendriksen CFM, et al. Humane endpoints in the efficacy testing of swine erysipelas vaccines. ALTEX. 2003;20:11-15.

109.United States Department of Agriculture. Center for Veterinary Biologics, Code of Federal Regulations, Title 9, Animals and Animal Products, Part 113-Standard Requirements, Section 113.67. Erysipelothrix Rhusiopathiae Vaccine.

110.United States Department of Agriculture, Center for Veterinary Biologics, Code of Federal Regulations, Title 9, Animals and Animal Products, Part 113-Standard Requirements, Section 113.326. Avian Pox Vaccineccine.

111. Kramer B, Bruckner L, Daas A, et al. Collaborative study for validation of a serological potency assay for rabies vaccine (inactivated) for veterinary use. Pharmeuropa Bio. 2010;37-55.

112.Kramer B, Schildger H, Behrensdorf-Nicol HA, et al. The rapid fluorescent focus inhibition test is a suitable method for batch potency testing of inactivated rabies vaccines. Biologicals. 2009;37:119-26.

113. Nagarajan T, Reddy GS, Mohana Subramanian B, et al. A simple immuno-capture ELISA to estimate rabies viral glycoprotein antigen in vaccine manufacture. Biologicals. 2006;34:21-7.

114. Rosskopf-Streicher U, Johannes S, Wilhelm M, et al. Quality control of inactivated erysipelas vaccines: results of an international collaborative study to establish a new regulatory test. Vaccine. 2001;19:1477-83.

115.United States Department of Agriculture, Center for Veterinary Biologics, Code of Federal Regulations, Title 9, Animals and Animal Products.Part 113-Standard Requirements.Section 113. SAM 613: Supplemental Assay Method for In vitro Potency Testing of Erysipelothrixrhusiopathiae Bacterins. 2009.

116.European Pharmacopoeia. Monograph 01/2010:0362. Clostridium novyi (type B) vaccine for veterinary use. 6th ed. Strasbourg, France: European Department for the Quality of Medicines within the Council of Europe. 2010.

117.EDQM. Alternative potency testing and other possible related quality issues for veterinary clostridial vaccines. Pharmeuropa, Special Issue, Bio 97-1. Strasbourg, France: European Department for the Quality of Medicines. 1997.

118.European Pharmacopoeia. Monograph 01/2008:0364. Clostridium septicum vaccine for veterinary use. 6th ed. Strasbourg, France: European Department for the Quality of Medicines within the Council of Europe. 2008.

119. Rosskopf-Streicher U, Volkers P, Noeske K, et al. Quality assurance of $\mathrm{C}$. perfringens epsilon toxoid vaccinesELISA versus mouse neutralisation test. Alternativenzu Tierexperimenten. 2004;21:65-9. 
120.United States Department of Agriculture, Center for Veterinary Biologics, SAM 217: Supplemental Assay Method for Potency Testing Tetanus Toxoid by ELISA. 2009.

121.European Pharmacopoeia. Monograph 01/2008:0697. Tetanus Vaccine for Veterinary Use. 6th ed. Strasbourg, France: European Department for the Quality of Medicines within the Council of Europe. 2008.

122.European Pharmacopoeia. Monograph 01/2008:0447. Canine Leptospirosis vaccine (inactivated). 6th ed. Strasbourg, France: European Department for the Quality of Medicines within the Council of Europe. 2008.

123.United States Department of Agriculture Center for Veterinary Biologics Testing Protocol. Supplemental Assay Method for In vitro Potency Testing of Leptospira interrogans serogroup canicola Bacterins. 2017;1-11.

124.United States Department of Agriculture Center for Veterinary Biologics Testing Protocol. Supplemental Assay Method for In vitro Potency Testing of Leptospira kirschneri serogroup grippotyphosa Bacterins. 2017;1-11.

125.United States Department of Agriculture Center for Veterinary Biologics Testing Protocol. Supplemental Assay Method for In vitro Potency Testing of Leptospira interrogans serogroup pomona Bacterins. 2017;1-11.

126.United States Department of Agriculture Center for Veterinary Biologics Testing Protocol. Supplemental Assay Method for In vitro Potency Testing of Leptospira interrogans serogroup icterohaemorrhagiae Bacterins. 2017;1-10.

127.European Pharmacopoeia. Monograph 01/2008:1939. Bovine leptospirosis vaccine (inactivated). 6th ed. Strasbourg, France: European Department for the Quality of Medicines within the Council of Europe. 2008.

128.United States Department of Agriculture, Center for Veterinary Biologics, Code of Federal Regulations, Title 9, Animals and Animal Products.Part 113-Standard Requirements.Section 113.209. SAM 308: Supplemental Assay Method for Potency Testing of Inactivated Rabies Vaccines in Mice Using the National Institutes of Health Test. 2007.

129.Bruckner L, Cussler K, Halder M, et al. Three Rs approaches in the quality control of inactivated rabies vaccines. The reportand recommendations of ECVAM Workshop 48. ALTA. 2003;31:429-54.

130. Correa de Moura W, Pinheiro de Araujo H, Cabello P. Potency evaluation of rabies vaccine for human use: the impact of the reduction in the number of animals per dilution. Journal of Virological Methods. 2009;158:84-92.

131.United States Department of Agriculture Center for Veterinary Biologics Testing Protocol. Supplemental Assay Method for Potency Testing of Inactivated Rabies Vaccine in Mice Using the National Institutes of Health Test. 2015;1-12.

132. United States Department of Agriculture, Center for Veterinary Biologics, Code of Federal Regulations, Title 9, Animals and Animal Products.Part 113-Standard Requirements.Section 113.65. SAM 600: Supplemental
Assay Method for Purity, Potency and Dissociation of Brucellabortus Vaccine, Strain 19. 2009.

133.United States Department of Agriculture, Center for Veterinary Biologics, Code of Federal Regulations, Title 9, Animals and Animal Products.Part 113- Standard Requirements.Section 113.67. SAM 612: Supplemental Assay Method for Bacterial Plate Count of Erysipelothrixrhusiopathiae Vaccines. 2007.

134. Section 113.68. SAM 905: Supplemental Assay Method for Test for Potency of Live AvirulentPasteurellahaemolytica Vaccine. 2009.

135.United States Department of Agriculture, Center for Veterinary Biologics, Code of Federal Regulations, Title 9, Animals and Animal Products.Part 113- Standard Requirements.Section 113.71. SAM 319: Supplemental Assay Method for Titration of Chlamydophilafelis(formerly Feline Chlamydia psittaci) in Embryonated Chicken Eggs. 2007.

136.United States Department of Agriculture, Center for Veterinary Biologics, Code of Federal Regulations, Title 9, Animals and Animal Products.Part 113- Standard Requirements.Section 113.314. SAM 306: Supplemental Assay Method for the Titration of Feline Calicivirus in Cell Culture. 2008.

137.United States Department of Agriculture, Center for Veterinary Biologics, Code of Federal Regulations, Title 9, Animals and Animal Products.Part 113- Standard Requirements.Section 113.315. SAM 307: Supplemental Assay Method for the Titration of Feline Rhinotracheitis Virus in Cell Culture. 2008.

138.United States Department of Agriculture, Center for Veterinary Biologics, Code of Federal Regulations, Title 9, Animals and Animal Products.Part 113- Standard Requirements.Section 113.330. SAM 406: Supplemental Assay Method for Titration of Monovalent, Cell Associated Marek's Disease Vaccines of Serotypes 1, 2 or 3. 2005.

139.European Pharmacopoeia. Monograph 01/2008:0589. Marek's disease vaccine (live). 7th ed. Strasbourg, France: European Department for the Quality of Medicines within the Council of Europe. 2010.

140.United States Department of Agriculture, Center for Veterinary Biologics, Code of Federal Regulations, Title 9, Animals and Animal Products.Part 113- Standard Requirements. SAM 121: Supplemental Assay Method for Titration of Porcine Rotovirus In Modified Live Vaccines. 2005.

141.United States Department of Agriculture, Center for Veterinary Biologics, Code of Federal Regulations, Title 9, Animals and Animal Products.Part 113- Standard Requirements.Section 113.305. SAM 304: Supplemental Assay Method for Titration of Infectious 31 Richard McFarland et al. / Procedia in Vaccinology 5 (2011) 16 3231 Richard McFarland et al. / Procediain Vaccinology 5 ( 2011 ) 16 - 32 Canine Hepatitis Virus in Primary Canine Kidney Cell Culture. 2007.

142.United States Department of Agriculture, Center for Veterinary Biologics, Code of Federal Regulations, Title 9, 
Citation: Suresh K, Mahendra PS, Vijay kB, et al. Quality control of vaccines-A journey from classical approach to 3Rs. Microbiol Curr Res. 2018;2(3):45-61.

Animals and Animal Products.Part 113- Standard Requirements.Section 113.306. SAM 323: Supplemental Assay Method for Titration of Canine Distemper Virus in Vero Cell Culture. 2007.

143.United States Department of Agriculture, Center for Veterinary Biologics, Code of Federal Regulations, Title 9, Animals and Animal Products.Part 113- Standard Requirements.Section 113.331. SAM 408: Supplemental Assay Method for Titrating Tissue Culture Adapted Vaccine Strains of Infectious Bursal Disease Virus. 2007.

144.United States Department of Agriculture, Center for Veterinary Biologics, Code of Federal Regulations, Title 9, Animals and Animal Products.Part 113- Standard Requirements.Section 113.304. SAM 305: Supplemental Assay Method for Titration of Feline Panleukopenia Virus in Cell Culture. 2007

145.United States Department of Agriculture, Center for Veterinary Biologics, Code of Federal Regulations, Title 9, Animals and Animal Products.Part 113- Standard Requirements.Section 113.302. SAM 303: Supplemental Assay Method for the Titration of Distemper Virus in Embryonated Chicken Eggs. 2007.

146.United States Department of Agriculture, Center for Veterinary Biologics, Code of Federal Regulations, Title 9, Animals and Animal Products.Part 113- Standard Requirements.Section 113.119. SAM 613: Supplemental Assay Method for InvitroPotency Testing of ErysipelothrixrhusiopathiaeBacterins. 2009.

147.United States Department of Agriculture, Center for Veterinary Biologics, Code of Federal Regulations, Title 9, Animals and Animal Products.Part 113- Standard
Requirements. SAM 120: Supplemental Assay Method for the in vitroPotency Assay of Bovine Respiratory Viruses in Killed Vaccines. 1991

148.Hendriksen C. Three Rs achievements in vaccinology. AATEX. 2007; 14:575-9.

149.Claassen I, Maas R, Oei H, et al. Validation study to evaluate the reproducibility of a candidate in vitropotency assay of Newcastle disease vaccines and to establish the suitability of a candidate biological reference preparation. Pharmeuropa Bio. 2004;1:1-15.

150.USDA Veterinary Services Memorandum 800. 2012.

151.NICEATM-sponsored workshop on alternatives for botulinum toxin testing. 2006.

152. Vasudevan. Potency determination of inactivated $\mathrm{H} 7$ influenza vaccines using monoclonal antibody-based ELISA and biolayer interferometry assays.Influenza Other Respi Viruses. 2017;1-9.

153.Forte J. In Dev R Receives NIH Support for VaxArray ${ }^{\circledR}$ Pandemic Influenza Vaccine Potency Test. 2017.

\section{*Correspondence to:}

Suresh Kumar

National Institute of Biologicals,

Ministry of Health \& Family Welfare,

Noida, Uttar Pradesh,

India

E-mail: suresh.kumar@nib.gov.in 